\title{
Eco-friendly kinetic separation of trans-limonene and carvomenthene oxides
}

\author{
S CHANDRAPPA SANTOSH KUMAR, JAVAGAL RANGASWAMY MANJUNATHA, \\ PULLABHATLA SRINIVAS and BHEEMANAKERE KEMAPAIAH BETTADAIAH* \\ Plantation Products, Spices and Flavour Technology Department, CSIR-Central Food Technological Research \\ Institute, Mysore 570 020, India \\ e-mail: bettadaiah@cftri.res.in
}

MS received 25 November 2013; revised 27 January 2014; accepted 29 January 2014

\begin{abstract}
Kinetic separation of trans-limonene oxide and trans-carvomenthene oxide was achieved in high yield by selective ring opening of their $\mathrm{cis}$-epoxides in the presence of $\mathrm{InCl}_{3}$ catalyst in water. Catalytic activity of $\mathrm{InCl}_{3}$ was conserved up to 10 cycles. Nucleophilic addition of methanol in presence of $\mathrm{InCl}_{3}$ was also selective as cis-epoxides preferentially reacted leaving behind trans-epoxides, which were separated by fractional distillation.
\end{abstract}

Keywords. Eco-friendly; kinetic separation; indium chloride; cis-/trans-limonene oxide; cis-Itrans-carvomenthene oxide; water.

\section{Introduction}

Chiral epoxides are versatile building blocks for the synthesis of biologically active, synthetically useful compounds such as fragrances, flavours, herbicides and fungicides. ${ }^{1}$ They also serve as starting materials for the asymmetric synthesis of natural products. ${ }^{2,3}$ Limonene, a cyclic monoterpene present in the essential oil of more than 300 plants and its $(R)-(+)$-enantiomer constitutes $90-96 \%$ of citrus peel oil. $(R)$-Limonene oxide is produced commercially as a cis- and trans-mixture (figure 1, 1a and $\mathbf{1 b}$ ) in $\sim 1: 1$ ratio. Due to its abundance availability and low cost, it is considered as bio-renewable source of epoxide for the preparation of biodegradable polymers such as polycarbonate and polyesters. $^{4}$

Epoxidation of carvomenthene (2) also affords cisItrans-epoxides (2a and $\mathbf{2 b}$ ) in $\sim 1: 1$ ratio. Separation of cis- and trans-epoxides from both limonene and carvomenthe is very difficult because of their close boiling range. Also, separation by column chromatography is not practicable because they elute together without separation. They are either synthesized by chemical or biological methods. ${ }^{5}$ The best way of separating individual epoxides is kinetic resolution method. Selective ring opening of epoxides has been effected by mercury salts, but requires an additional de-metallation step. ${ }^{6}$ Base-induced cleavage of cis- or trans-epoxides affords

\footnotetext{
*For correspondence
}

separation of either of the epoxide depending upon choice of the base, but the reactions are usually effected at elevated temperatures. ${ }^{7}$ Molybdenum complex has also been used for the kinetic resolution of monocyclic terpene epoxides. ${ }^{8}$ Hydrolytic kinetic resolution gives pure epoxides but needs a specific catalyst and applicable to terminal epoxides. ${ }^{9}$ Racemic chromium salen complex has been found to effect kinetic resolution in case of monocyclic terpene epoxides containing C-4 substituent. ${ }^{10} \mathrm{We}$, earlier reported kinetic resolution of terpene oxides in methanol in the presence of Lewis acid catalysts. ${ }^{11}$ In this photo-catalysed stereo-differentiation, cis-epoxides cleaved preferentially compared to trans-epoxides in the presence of Lewis acids catalysts. In order to develop an efficient eco-friendly kinetic separation of cis-/trans-limonene oxide, and cis-/trans-carvomenthene oxide, we checked the reactivity of these in water in the presence of Lewis acid catalyst such as $\mathrm{InCl}_{3}$. This catalyst was chosen as many transition metal catalysts have low adaptability to water when compared to $\mathrm{InCl}_{3}$, which on the other hand has a good tolerance of moisture. ${ }^{12}$

Firstly, the reaction of mixture of $\mathbf{1 a}$ and $\mathbf{1 b}$ in the presence of $10 \mathrm{~mol} \% \mathrm{InCl}_{3}$ in water was carried out. It resulted in the cleavage of cis-epoxide leaving behind trans-epoxide (scheme 1). Upon fractional distillation of products, $\mathbf{1 b}$ was separated from $\mathbf{1 d}$. Hence, a detail study was undertaken, which resulted in development of an efficient eco-friendly kinetic separation method for trans-limonene oxide. Scope of the reaction for 


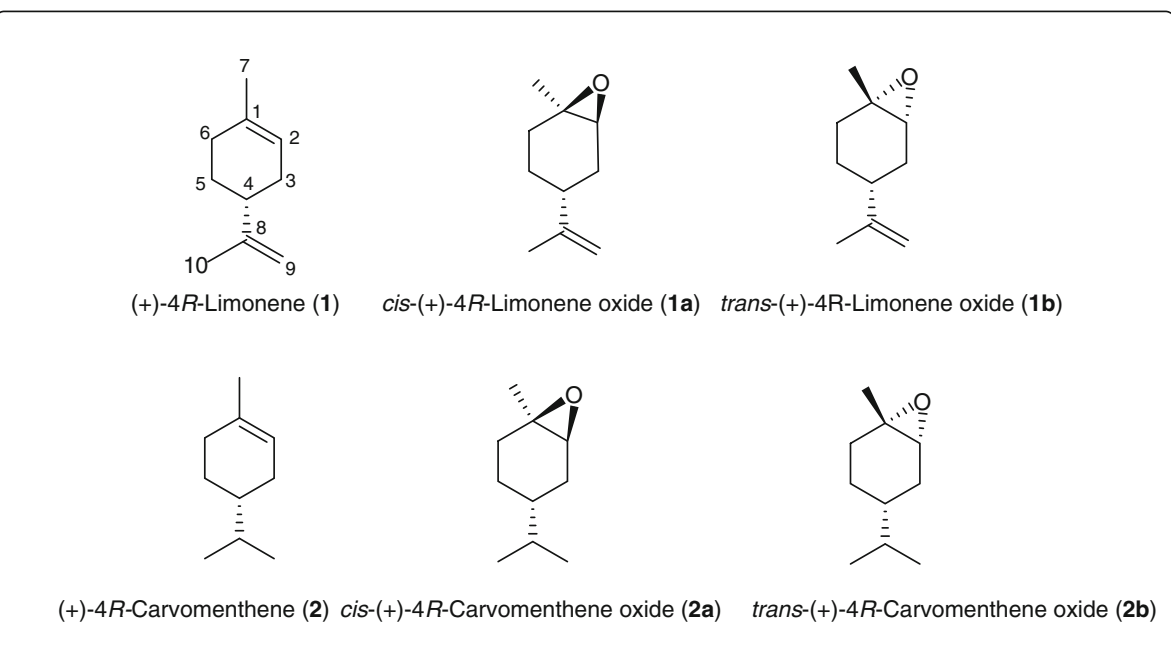

Figure 1. Structures of $4 R$-limonene, cis-/trans-limonene oxides, $4 R$-carvomenthene, and cis-/trans-carvomenthene oxides.
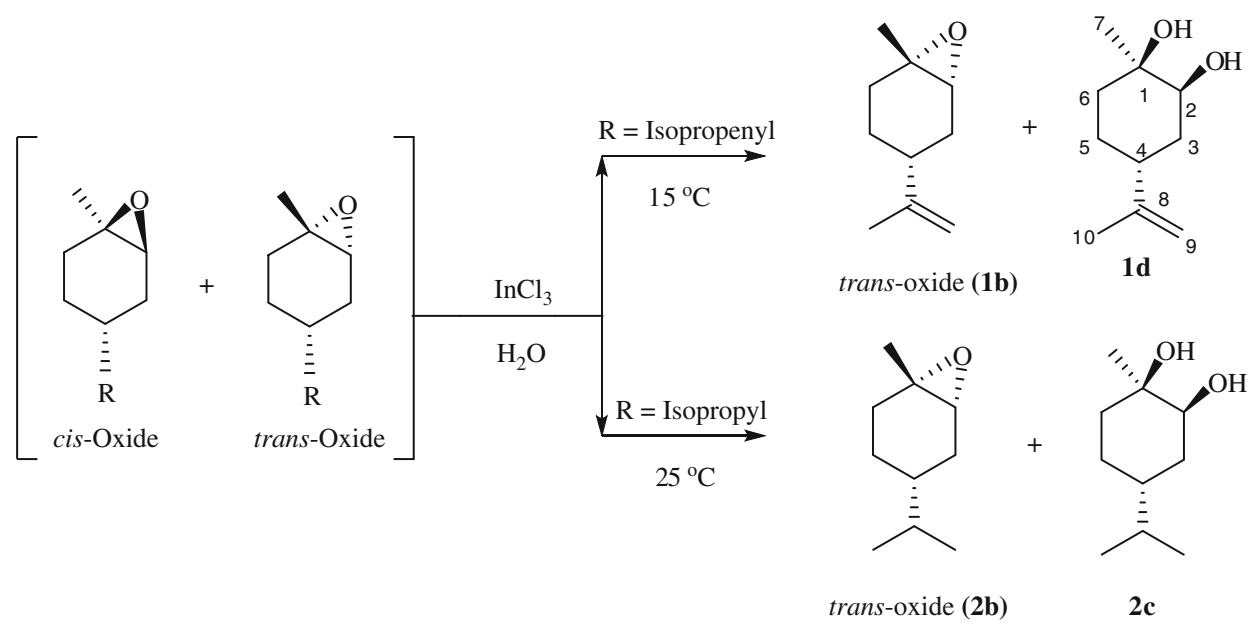

Scheme 1. Reaction of cis/trans-limonene and carvomenthene oxides in water in the presence of $\mathrm{InCl}_{3}$.

kinetic separation of trans-carvomenthene oxide from cis-Itrans-mixture (2a and $\mathbf{2 b}$ ) was also demonstrated.

\section{Experimental}

\subsection{Separation of trans-limonene and carvomenthene oxides in water}

In a two-necked RB flask, a mixture of cis-/transepoxide $(30 \mathrm{mmol})$ in triple distilled water $(50 \mathrm{ml})$ and $\mathrm{InCl}_{3}(3 \mathrm{mmol})$ was stirred at $10-15^{\circ} \mathrm{C}$ in case of limonene oxide and $25^{\circ} \mathrm{C}$ in case of carvomenthene oxide. The mixture was similar to an emulsion at the beginning, which turned hazy during the reaction. Progress of reaction was checked by NMR for the complete disappearance of proton attached to epoxide ring at position 2 in $\mathbf{1 a}$ and $\mathbf{2 a}$, respectively, at 3.06 and $3.01 \mathrm{ppm}$. After the complete reaction of cis-isomer, the mixture was extracted with $\mathrm{CH}_{2} \mathrm{Cl}_{2}$ $(30 \mathrm{ml} \times 3)$. The combined organic extracts were dried over anhydrous $\mathrm{Na}_{2} \mathrm{SO}_{4}$ and evaporated to afford the crude product, which was purified by fractional distillation under reduced pressure. Physical and spectral data of the isolated compounds is presented here.

2.1a trans-Limonene-oxide (1b): Yield $2.40 \mathrm{~g}$, (97\%); b.p. $78-80^{\circ} \mathrm{C} / 1.33 \mathrm{kPa},\left(\right.$ ref. $\left.^{13}\right)$ : $57-59^{\circ} \mathrm{C} / 0.33$ $\mathrm{kPa} ;[\alpha]_{20}^{\mathrm{D}}=+74^{\circ}(c=1, \mathrm{MeOH}),\left(\right.$ ref. $\left.^{14}\right):+82^{\circ}$; ${ }^{1} \mathrm{H}$ NMR $\left(500 \mathrm{MHz}, \mathrm{CDCl}_{3}\right): \delta=4.66\left(\mathrm{~s}, 2 \mathrm{H},-\mathrm{CH}_{2}\right)$, $2.98(\mathrm{~d}, 1 \mathrm{H}, J=5.3 \mathrm{~Hz},-\mathrm{CH}), 2.00-2.05(\mathrm{~m}, 2 \mathrm{H}$, $\left.-\mathrm{CH}_{2}\right), 1.84-1.89(\mathrm{~m}, 1 \mathrm{H}), 1.68-1.72\left(\mathrm{~m}, 2 \mathrm{H},-\mathrm{CH}_{2}\right)$, $1.66\left(\mathrm{~s}, 3 \mathrm{H},-\mathrm{CH}_{3}\right), 1.35-1.39\left(\mathrm{~m}, 2 \mathrm{H},-\mathrm{CH}_{2}\right), 1.31$ $\left(\mathrm{s}, 3 \mathrm{H},-\mathrm{CH}_{3}\right) ;{ }^{13} \mathrm{C}$ NMR $\left(125 \mathrm{MHz}, \mathrm{CDCl}_{3}\right): \delta=$ 148.8, 108.7, 58.9, 57.1, 40.4, 30.4, 29.5, 24.02, 22.7, 
19.8; MS $(m / z): 152(2), 137(8), 119(9), 108(76)$, 94(89), 79(51), 67(93), 43(100)

$2.1 \mathrm{~b}$ trans-Carvomenthene-oxide (2b): Yield $2.45 \mathrm{~g}$, (96.4\%); b.p. $73-75^{\circ} \mathrm{C} / 0.66 \mathrm{kPa},[\alpha]_{20}^{\mathrm{D}}=+48^{\circ}(c=1$, $\mathrm{MeOH}) ;{ }^{1} \mathrm{H}$ NMR $\left(500 \mathrm{MHz}, \mathrm{CDCl}_{3}\right): \delta=2.96(\mathrm{~d}$, $1 \mathrm{H}, J=5.3 \mathrm{~Hz},-\mathrm{CH}), 1.91-2.00\left(\mathrm{~m}, 2 \mathrm{H},-\mathrm{CH}_{2}\right), 1.61$ $\left(\mathrm{ddd}, 1 \mathrm{H}, J_{1}=14.51 \mathrm{~Hz}, J_{2}=12.21 \mathrm{~Hz}, J_{3}=4.8 \mathrm{~Hz}\right.$ ) $1.51\left(\mathrm{dd}, 1 \mathrm{H}, J_{1}=15.0, J_{2}=11.62,-\mathrm{CH}_{2}\right), 1.37$ (sept, $1 \mathrm{H}, J=6.73 \mathrm{~Hz},-\mathrm{CH}), 1.29\left(\mathrm{~s}, 3 \mathrm{H},-\mathrm{CH}_{3}\right), 1.10(\mathrm{dq}$, $\left.2 \mathrm{H}, J_{1}=12.46 \mathrm{~Hz}, J_{2}=4.16 \mathrm{~Hz},-\mathrm{CH}_{2}\right), 1.01(\mathrm{ds}, 1 \mathrm{H}$, $\left.J_{1}=6.15 \mathrm{~Hz}, J_{2}=2.05 \mathrm{~Hz},-\mathrm{CH}\right), 0.82(\mathrm{~d}, 6 \mathrm{H}, J=$ $\left.6.92 \mathrm{~Hz},-\mathrm{CH}_{3}\right) ;{ }^{13} \mathrm{C}$ NMR $\left(125 \mathrm{MHz}, \mathrm{CDCl}_{3}\right): \delta=$ 59.2, 57.4, 38.9, 31.9, 30.6, 27.5, 22.7, 22.1, 19.3, 18.9; $\operatorname{MS}(m / z): 154(2), 139(20), 125(13), 111(46), 97(9)$, 83(20), 69(24), 55(32), 43(100).

2.1c (1S,2S,4R)-1-methyl-4-(prop-1-en-2-yl)cyclohexane-1,2-diol (1d): b.p. $115-117^{\circ} \mathrm{C} / 0.46 \mathrm{kPa}$; $[\alpha]_{20}^{\mathrm{D}}=+42^{\circ}(c=1, \mathrm{MeOH})$; Yield: $2.1 \mathrm{~g}(90 \%) ;{ }^{1} \mathrm{H}$ NMR (500 MHz, $\left.\mathrm{CDCl}_{3}\right): \delta=4.72\left(\mathrm{~s}, 2 \mathrm{H},-\mathrm{CH}_{2}\right), 3.61$ (t, $1 \mathrm{H}, J=3.12 \mathrm{~Hz},-\mathrm{CH}), 2.21-2.29(\mathrm{~m}, 1 \mathrm{H},-\mathrm{CH})$, $1.91\left(\mathrm{ddd}, 1 \mathrm{H}, J_{1}=13.99 \mathrm{~Hz}, J_{2}=11.47 \mathrm{~Hz}, J_{3}=\right.$ $\left.2.84 \mathrm{~Hz},-\mathrm{CH}_{2}\right), 1.72-1.77\left(\mathrm{~m}, 1 \mathrm{H},-\mathrm{CH}_{2}\right), 1.71(\mathrm{~s}, 3 \mathrm{H})$, 1.61-1.66 (m, $\left.1 \mathrm{H},-\mathrm{CH}_{2}\right), 1.52-1.56\left(\mathrm{~m}, 2 \mathrm{H},-\mathrm{CH}_{2}\right)$, $1.47-1.52\left(\mathrm{~m}, 1 \mathrm{H},-\mathrm{CH}_{2}\right), 1.24\left(\mathrm{~s}, 3 \mathrm{H},-\mathrm{CH}_{3}\right) ;{ }^{13} \mathrm{C}$ NMR $\left(125 \mathrm{MHz}, \mathrm{CDCl}_{3}\right): \delta=148.9,108.6,73.5,71.1$, 37.1, 33.6, 33.3, 26.1, 25.8, 20.7; MS $(m / z): 170(2)$, 152(34), 137(21), 111(21), 108(46), 93(40),82(35), 71(80), 67(46), 55(32), 43(100).

2.1d (1S,2S,4R)-4-isopropyl-1-methylcyclohexane-1, 2-diol (2c): b.p. $123-125^{\circ} \mathrm{C} / 0.46 \mathrm{kPa}$; $[\alpha]_{20}^{\mathrm{D}}=+43^{\circ}$ $(c=1, \mathrm{MeOH})$; Yield $2 \mathrm{~g},(85 \%) ;{ }^{1} \mathrm{H}$ NMR $(500 \mathrm{MHz}$, $\left.\mathrm{CDCl}_{3}\right): \delta=3.59(\mathrm{t}, 1 \mathrm{H}, J=3.45 \mathrm{~Hz},-\mathrm{CH}), 1.93(\mathrm{br}$, $2 \mathrm{H}$, $-\mathrm{OH}$ confirmed by D exchange), 1.64-1.74 (m, $2 \mathrm{H}$, $\left.-\mathrm{CH}_{2}\right), 1.56-1.61\left(\mathrm{~m}, 1 \mathrm{H},-\mathrm{CH}_{2}\right), 1.50-1.53(\mathrm{~m}, 1 \mathrm{H}$, $\left.-\mathrm{CH}_{2}\right), 1.46-1.50\left(\mathrm{~m}, 2 \mathrm{H},-\mathrm{CH}_{2}\right), 1.33-1.38(\mathrm{~m}, 2 \mathrm{H}$, $-\mathrm{C}(4) \mathrm{H}$ and $\left.-\mathrm{C}(5) \mathrm{H}_{2}\right), 1.24\left(\mathrm{~s}, 3 \mathrm{H},-\mathrm{CH}_{3}\right), 0.88(\mathrm{t}, 6 \mathrm{H}$, $\left.J=7.54 \mathrm{~Hz},-\mathrm{CH}_{3}\right) ;{ }^{13} \mathrm{C} \mathrm{NMR}\left(125 \mathrm{MHz}, \mathrm{CDCl}_{3}\right)$ : $\delta=73.7,36.4,33.4,32.3,31.0,29.3,25.8,23.9,19.7$, 19.6; MS $(\mathrm{m} / \mathrm{z}): 172(8), 154(4), 139(11), 111(52)$, 97(13), 83(28), 71(100), 55(48), 43(91).

\subsection{General procedure for separation of}

trans-limonene and carvomenthene oxides in methanol

In a two-necked RB flask, a solution of cis-/transepoxide $(30 \mathrm{mmol})$ in methanol $(50 \mathrm{ml})$ and $\mathrm{InCl}_{3}$ ( $3 \mathrm{mmol}$ ) was taken. The solution was stirred at room temperature. Progress of the reaction was checked by NMR for the complete disappearance of proton attached to epoxide ring at position 2 in $\mathbf{1 a}$ and $\mathbf{2 a}$, respectively, at 3.06 and $3.01 \mathrm{ppm}$. After the reaction was complete $(4 \mathrm{~h})$, methanol was evaporated and the products were extracted into $\mathrm{CH}_{2} \mathrm{Cl}_{2}(30 \mathrm{ml} \times 3)$ by aqueous work-up. The combined organic extracts was dried over $\mathrm{Na}_{2} \mathrm{SO}_{4}$ and concentrated to afford the crude product. It was then purified by fractional distillation under reduced pressure to afford pure products. Physical and spectral data of isolated compounds is presented here.

2.2a (1S,2S,4R)-2-hydroxy-1-methoxy-p-menthan8(9)-ene (1c): Yield 2.16g, (85\%); b.p. 115-117 $\mathrm{C} / 0.66 \mathrm{kPa} ;[\alpha]_{20}^{\mathrm{D}}=+39^{\circ} ;{ }^{1} \mathrm{H}$ NMR $(500 \mathrm{MHz}$, $\left.\mathrm{CDCl}_{3}\right): \delta=4.72\left(\right.$ br s, $\left.2 \mathrm{H}, \mathrm{CH}_{2}\right), 3.68(\mathrm{~s}, 1 \mathrm{H}, \mathrm{CH})$, $3.19\left(\mathrm{~s}, 3 \mathrm{H}, \mathrm{OCH}_{3}\right), 2.24\left(\mathrm{tt}, 1 \mathrm{H}, J_{1}=11.70 \mathrm{~Hz}\right.$, $\left.J_{2}=3.52 \mathrm{~Hz}, \mathrm{CH}\right), 1.91\left(\mathrm{ddd}, 1 \mathrm{H}, J_{1}=13.64 \mathrm{~Hz}, J_{2}\right.$ $\left.=12.29 \mathrm{~Hz}, J_{3}=2.69 \mathrm{~Hz}, \mathrm{CH}_{2}\right), 1.80(\mathrm{br}, 1 \mathrm{H}, \mathrm{OH})$, $1.72\left(\mathrm{~s}, 3 \mathrm{H}, \mathrm{CH}_{3}\right), 1.70\left(\mathrm{dt}, 1 \mathrm{H}, J_{1}=3.72 \mathrm{~Hz}, J_{2}=\right.$ $\left.1.35 \mathrm{~Hz}, \mathrm{CH}_{2}\right), 1.62\left(\mathrm{~m}, 1 \mathrm{H}, \mathrm{CH}_{2}\right), 1.56\left(\mathrm{dt}, 1 \mathrm{H}, J_{1}=\right.$ $\left.13.64 \mathrm{~Hz}, J_{2}=1.77 \mathrm{~Hz}, \mathrm{CH}_{2}\right), 1.37-1.51\left(\mathrm{~m}, 2 \mathrm{H}, \mathrm{CH}_{2}\right)$, $1.18\left(\mathrm{~s}, 3 \mathrm{H}, \mathrm{CH}_{3}\right) ;{ }^{13} \mathrm{C}$ NMR $\left(125 \mathrm{MHz}, \mathrm{CDCl}_{3}\right)$ : $\delta=149.4,108.4,74.8,72.0,48.0,37.1,33.5,28.5$, 25.7, 20.6, 19.9; MS (m/z): 184(2), 169(4), 152(10), 108(15), 85(100), 72(21), 55(19), 43(16).

$2.2 \mathrm{~b} \quad(1 S, 2 S, 4 R)$-2-hydroxy-1-methoxy-p-menthane (2d): Yield $2.17 \mathrm{~g},(86.8 \%)$; b.p. $102-104^{\circ} \mathrm{C} / 0.33 \mathrm{kPa}$; $[\alpha]_{20}^{\mathrm{D}}=33^{\circ}(c=1, \mathrm{MeOH}) ;{ }^{1} \mathrm{H}$ NMR $(500 \mathrm{MHz}$, $\left.\mathrm{CDCl}_{3}\right): \delta=3.62(\mathrm{~s}, 1 \mathrm{H}, \mathrm{CH}), 3.17\left(\mathrm{~s}, 3 \mathrm{H}, \mathrm{CH}_{3}\right)$, 2.40 (br, $1 \mathrm{H}, \mathrm{OH}), 1.63-1.72\left(\mathrm{~m}, 2 \mathrm{H},-\mathrm{C}(3) \mathrm{H}_{2}\right.$ and $\left.-\mathrm{C}(6) \mathrm{H}_{2}\right), 1.52-1.59\left(\mathrm{~m}, 1 \mathrm{H},-\mathrm{CH}_{2}\right), 1.50(\mathrm{dd}, 1 \mathrm{H}$, $\left.J_{1}=12.95 \mathrm{~Hz}, J_{2}=3.59 \mathrm{~Hz},-\mathrm{CH}_{2}\right), 1.43-1.47(\mathrm{~m}$, $1 \mathrm{H},-\mathrm{CH}), 1.40-1.43\left(\mathrm{~m}, 1 \mathrm{H},-\mathrm{CH}_{2}\right), 1.32-1.38(\mathrm{~m}$, $1 \mathrm{H},-\mathrm{CH}), 1.18-1.22\left(\mathrm{~m}, 1 \mathrm{H},-\mathrm{CH}_{2}\right), 1.15(\mathrm{~s}, 3 \mathrm{H}$, $\left.-\mathrm{CH}_{3}\right), 0.87\left(\mathrm{t}, 6 \mathrm{H}, J=6.67 \mathrm{~Hz},-\mathrm{CH}_{3}\right) ;{ }^{13} \mathrm{C} \mathrm{NMR}$ $\left(125 \mathrm{MHz}, \mathrm{CDCl}_{3}\right): \delta=75.2,72.2,48.0,36.2,32.0$, $31.5,28.6,23.7,19.8,19.7,19.5$; MS $(m / z): 186(6)$, 171(4), 154(4), 143(4), 136(11), 125(2), 111(10), 97(2), 85(100), 83(4), 72(20), 55(17), 43(13).

\subsection{Catalyst reusability test}

Retention of catalytic activity of $\mathrm{InCl}_{3}$ was checked by carrying out reaction over 10 cycles. Under each cycle, the reaction was carried out on $10 \mathrm{mmol}$ scale, after completion of the reaction, the usual work-up afforded the mixture of trans-epoxide and 1d. The aqueous layer obtained at work-up stage, was separated and utilized for succeeding reactions. The sequence of operation was followed in every subsequent cycle 
and repeated for 10 times. The data of distribution of cis- and trans-epoxides over 10 cycles is presented in table 1. It was observed that in every cycle, stereodifferentiation between the cis- and trans-epoxides was observed which indicates the catalytic role of $\mathrm{InCl}_{3}$ in water. It was seen that the rate of reactions for initial cycles was within $5 \mathrm{~h}$ and further it gradually reduced from 3rd to 10th cycle.

\section{Results and discussion}

Commercial limonene oxide containing $\mathbf{1 a}$ and $\mathbf{1 b}$ in $\sim 1: 1$ ratio was taken for the reaction in presence of $10 \mathrm{~mol} \%$ of $\mathrm{InCl}_{3}$ in water (scheme 1). Progress of reaction was monitored by NMR. The reaction at $25^{\circ} \mathrm{C}$ was found to be fast as both cis-oxide and trans-oxide underwent cleavage and afforded a mixture of diaxial diols as products. Hence, under these conditions, the kinetic diastereo-differentiation was not apparent. However, at a lower temperature of $10-15^{\circ} \mathrm{C}$, the reaction was found to proceed towards selective cleavage of cis-oxide and trans-oxide remained un-reactive. The trans-epoxide 1b did not react upon prolonged agitation for up to $24 \mathrm{~h}$. Hence, the reaction under said conditions was diastereo-differentiating between cisand trans-epoxides. In the course of the reaction at $5 \mathrm{~h}$, components of the system were trans-diaxial diol (1d) formed by cleavage of cis-oxide and un-reacted trans-oxide. Since these products have different in boiling ranges, they were separated by fractional distillation under reduced pressure. After the separation, the trans-epoxide was confirmed by comparison with standard trans-limonene oxide (NMR). The standard trans-limonene oxide was synthesized via $\beta$-bromotert-alcohol intermediate, by reacting limonene with

Table 1. Reaction of cis/trans-limonene oxide in water in presence of $10 \% \mathrm{InCl}_{3}$.

\begin{tabular}{lccc}
\hline & \multicolumn{2}{c}{$\%$ oxide in $5 \mathrm{~h}$} & \\
\cline { 2 - 3 } Cycle No. & cis-oxide & trans-oxide & Time $(\mathrm{h})^{\mathrm{a}}$ \\
\hline 1 & 0 & 54 & 5.0 \\
2 & 0 & 54 & 5.0 \\
3 & 2 & 54 & 5.5 \\
4 & 7 & 54 & 6.0 \\
5 & 12 & 54 & 7.5 \\
6 & 17 & 54 & 8.5 \\
7 & 22 & 54 & 10.0 \\
8 & 27 & 54 & 13.0 \\
9 & 30 & 54 & 16.0 \\
10 & 33 & 54 & 18.0 \\
\hline
\end{tabular}

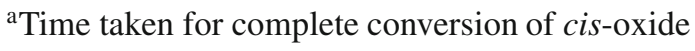

$\mathrm{N}$-bromosuccinimide (NBS) in aqueous acetone followed by treatment with $\mathrm{Na}_{2} \mathrm{CO}_{3}$ in aqueous ethanol. ${ }^{15}$ The characteristic doublet signal for the proton attached to epoxide at $2.98 \mathrm{ppm}$ in trans-epoxide (1b) was confirmed with standard trans-epoxide by NMR experiment. Kinetics of the reaction of cis-/trans-limonene oxide and cis-/trans-carvomenthene oxide with respect to time is presented in figure 2 .

Next, the reaction of cis-/trans-limonene oxide in the presence of $\mathrm{InCl}_{3}(10 \mathrm{~mol} \%)$ in methanol was carried out (scheme 2). It was found that 1a reacted faster and afforded the ring cleaved product 1c leaving behind $\mathbf{1 b}$ unaffected. Easy separation of transepoxide was accomplished by fractional distillation under reduced pressure as $\mathbf{1 b}$ and $\mathbf{1 c}$ had different boiling ranges. Graphical representation of progress of the reaction of mixture cis-/trans-limonene oxide and cis/trans-carvomenthene oxide in methanol is presented in figure 3.

Further, the reaction was checked with cis-/transcarvomenthene oxide (schemes 1 and 2). Carvomenthene was prepared by hydrogenation of $R-(+)-$ limonene using Raney nickel catalyst. It was then distilled to afford pure carvomenthene. Its epoxide was prepared using peracetic acid (30\%) oxidation. The cisItrans-carvomenthene oxides were not well-resolved by GC analysis. The cis-/trans ratio was checked by NMR. Integration of proton attached to oxirane ring at 2nd position in cis-epoxide appeared as broad singlet at $3.01 \mathrm{ppm}$ integrated to 0.45 units, whereas transepoxide appeared as doublet at $2.95 \mathrm{ppm}$ integrated to 0.55 units, hence, the ratio of cis- to trans-oxide was taken as 45:55. Pure trans-epoxide of carvomenthene

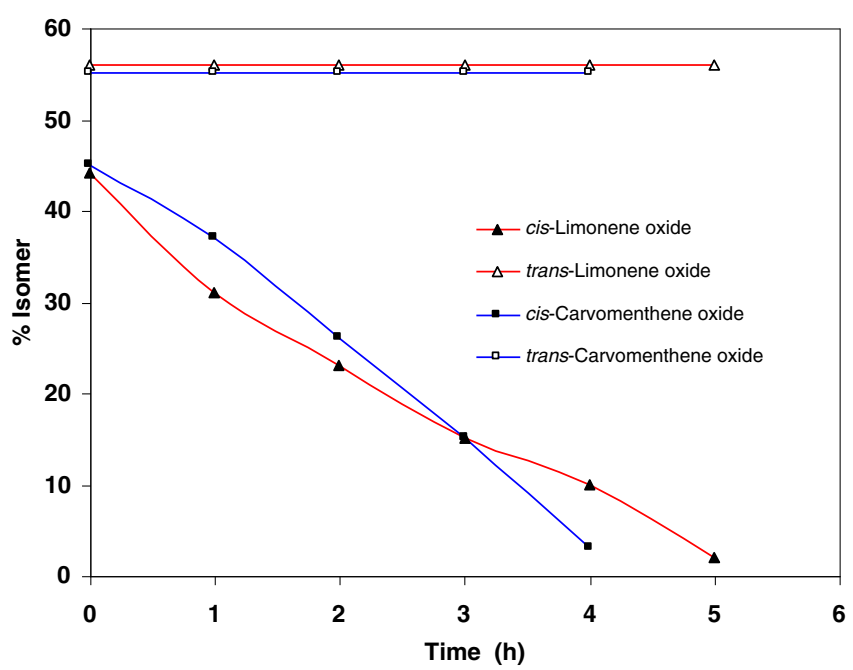

Figure 2. Kinetics of the reaction of cis/trans-limonene and carvomenthene oxides in water in the presence of $\mathrm{InCl}_{3}$. 


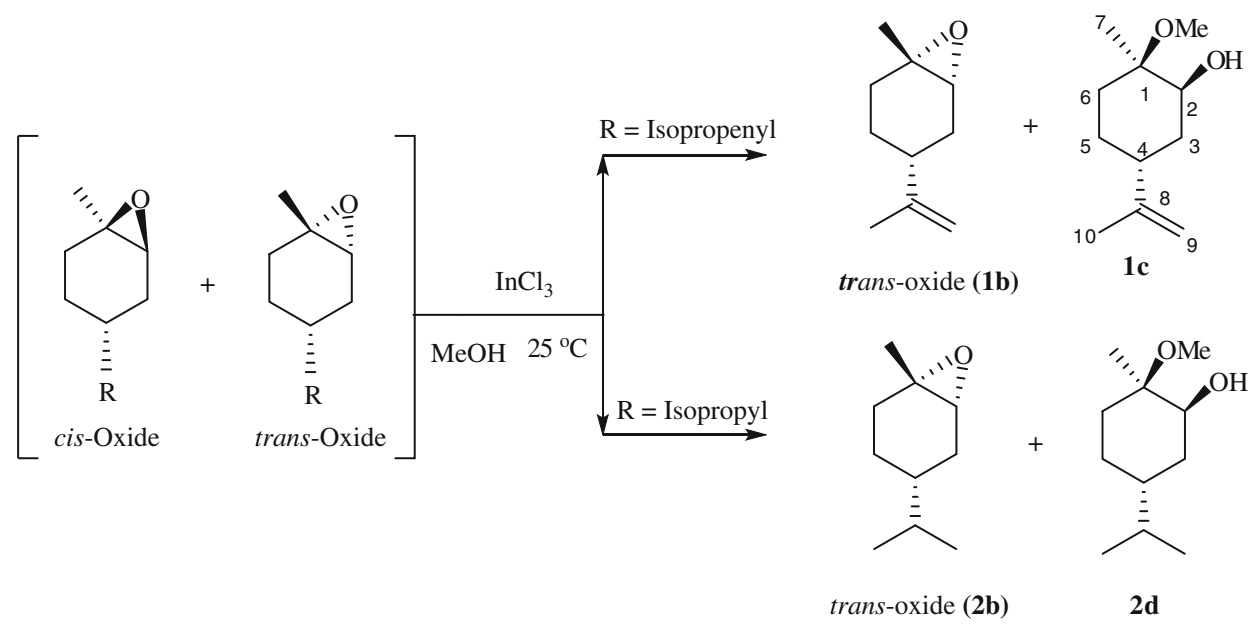

Scheme 2. Reaction of cis/trans-limonene and carvomenthene oxides in methanol in the presence of $\mathrm{InCl}_{3}$.

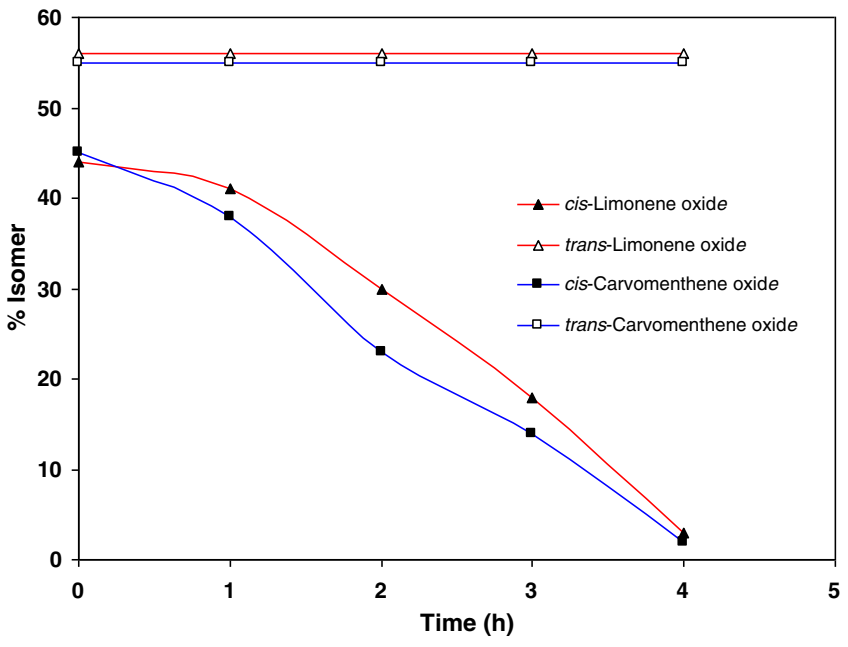

Figure 3. Kinetics of the reaction of cis/trans-limonene oxide and cis/trans-carvomenthene oxide in methanol in the presence of $\mathrm{InCl}_{3}$. was also prepared via $\beta$-bromo-tert-alcohol intermediate by reacting carvomenthene with NBS followed by treatment with $\mathrm{Na}_{2} \mathrm{CO}_{3}$ in aqueous ethanol. ${ }^{15}$ Reaction of cis-/trans-carvomenthene oxides in presence of $\mathrm{InCl}_{3}$ in water occurred at a similar rate and was completed in $4 \mathrm{~h}$ leaving behind un-reacted trans-carvomenthene oxide $\mathbf{2 b}$ (scheme 1). The reaction was checked at $25^{\circ} \mathrm{C}$ with $10 \% \mathrm{InCl}_{3}$. Trans-carvomenthene oxide remained un-reactive during the time in which cis-carvomenthene oxide completely reacted affords resolution of transepoxide. The rate of reaction versus percent cis-/transoxide is plotted (figure 2). The reaction when performed at $5-10^{\circ} \mathrm{C}$ and $10-15^{\circ} \mathrm{C}$ was also found to be selective but rate of reaction was slow.

In the reaction using methanol as a solvent, ciscarvomenthene oxide reacted selectively to give 1methoxy-2-hydroxy- $p$-menthane as the product, while

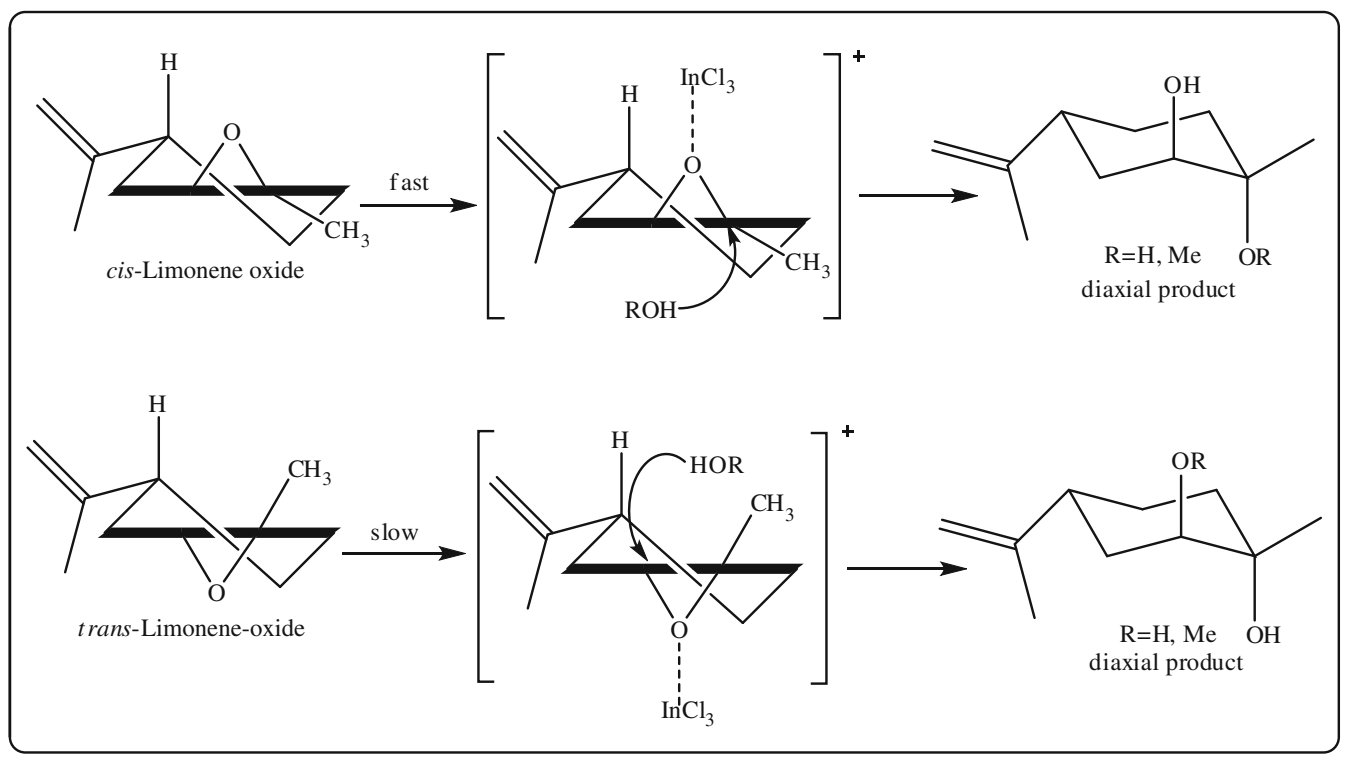

Scheme 3. $\mathrm{InCl}_{3}$-catalysed solvolysis of cis-/trans-limonene oxide. 
trans-oxide remain un-reacted (scheme 2). The mixture of un-reacted trans-oxide and chiral product $\mathbf{2 d}$ were separated by fractional distillation. The rate of reaction versus time is presented in figure 3 .

A plausible explanation for the kinetic separation of trans-limonene oxide and trans-carvomenthene oxide in water and methanol in presence of $\mathrm{InCl}_{3}$ is presented in scheme 3. The isopropenyl group occupies equatorial position in both cis- and trans-oxides due to inherent conformational differences. ${ }^{7}$ Interaction of indium chloride with oxirane oxygen followed by its opening takes place fast in case of cis-oxide. Nucleophilic substitution takes place at more substituted carbon (C-1) due to more $\mathrm{S}_{\mathrm{N}} 1$ character. Interaction of indium chloride with oxirane oxygen in case of trans-oxide is relatively slower and its opening with nucleophile leading to diaxial product takes place with nucleophile sitting on C-2 according to Furst-Plattner rule. ${ }^{7}$ Hence, this difference in reactivity between cis- and trans-oxide with Lewis acid towards nucleophilic substitution facilitates kinetic separation of trans-oxide over cis-oxide by stopping the reaction at appropriate time.

\section{Conclusions}

In summary, we report a new and environment-friendly kinetic separation protocol for trans-limonene and carvomenthene oxides. An easily available and inexpensive $\mathrm{InCl}_{3}$ was employed to achieve kinetic separation in a simple experimental protocol. Catalytic activity of $\mathrm{InCl}_{3}$ was found to be effective up to 10 cycles. When compared to existing methods for kinetic separation, the method is superior in affording separation of terpeneepoxides in quantitative yield. The present methodology also works well in the presence of an alcoholic solvent such as methanol.

\section{Supplementary information}

The electronic supplementary material contains ${ }^{1} \mathrm{H}$ NMR, ${ }^{13} \mathrm{C}$ NMR and mass spectra of compounds $\mathbf{1 b}$, 1c, $\mathbf{1 d}, \mathbf{2 b}, \mathbf{2 c}$ and $\mathbf{2 d}$, which can be seen in www.ias.as. in/chemsci.

\section{Acknowledgements}

The author SCSK thanks the University Grants Commission, New Delhi for Junior Research Fellowship. The authors also thank Mr. Shivaswamy, Central Instruments Facility and Services department, CFTRI, Mysore for GC-MS analysis.

\section{References}

1. Bauer K, Garbe D and Surburg H 1997 In Common fragrance and flavour materials, preparation, properties and uses (New York: Wiley VCH)

2. (a) Comins D, Weltzien L G and Salvador J M 1994 Synlett 11 972; (b) Chrisman W, Camara J N, Marcellini K, Singaram B, Goralski C T, Hasha D L, Rudolf P R, Nicholson L W and Borodychuk K K 2001 Tetrahedron Lett. 425805

3. Lebel H and Jacobsen E N 1998 J. Org. Chem. 639624

4. (a) Byrne C M, Allen S D, Lobkovsky E B and Coates G W 2004 J. Am. Chem. Soc. 126 11404; (b) Jeske R C, Diciccio A M and Coates G W 2007 J. Am. Chem. Soc. 12911330

5. (a) Besse P and Veschambre H 1994 Tetrahedron 50 8885; (b) Churing S V and Betchinger F 1992 Chem. Rev. 92 873; Archelas A and Furstoss R 1997 Annu. Rev. Microbiol. 51491

6. van der Werf M J, Jongejan H and Maurice Franssen C R 2001 Tetrahedron Lett. 425521

7. Steiner D, Ivison L, Goralski C T, Appell R B, Gojkovic J R and Singaram B 2002 Tetrahedron: Asymmetry 13 2359

8. Cole-Hamilton D J, Salles L, Nixon A F, Russell N C, Clarke R and Pogorzelec P 1999 Tetrahedron: Asymmetry 101471

9. Tokunaga M, Larrow J F, Kakiuchi F and Jacobsen E N 1997 Science 277936

10. Bart Dioos M L and Pierre Jacobs A 2003 Tetrahedron Lett. 444715

11. Bettadaiah B K and Srinivas P 2004 J. Photochem. Photobiol. A167 137

12. (a) Loh T P and Chua G L 2006 Chem. Commun. 2739; (b) Sun H B, Chen W L, Sun Y H, Qin P and Qi X 2011 Adv. Mater. Res. 396-398 2416

13. Royals E E and Leffingwell J C 1966 J. Org. Chem. 31 1937

14. Sanseverino A M, da Silva F M, Jones J J and de Mattos M C S 2000 J. Braz. Chem. Soc. 11381

15. Gurudutt K N, Rao S and Srinivas P 1992 Flav. Fragr. J. 7343 